\title{
Invasion of Japanese shores by the NE Pacific barnacle Balanus glandula and its ecological and biogeographical impact
}

\author{
Ryusuke Kado* \\ School of Fisheries Sciences, Kitasato University, Sanriku, Ofunato, Iwate 022-0101, Japan
}

\begin{abstract}
A common littoral barnacle, Balanus glandula Darwin, 1854 (Crustacea, Cirripedia) from the west coast of North America has become established in the mid-littoral zone of harbors on the Pacific side of northern Honshu, Japan. The new immigrant occupies space in the lower half of the Chthamalus spp. and Balanus albicostatus zones, and in the upper fringe of the Semibalanus cariosus zone. However, the species has not been detected in harbors along the Sea of Japan, south of the Ozika Peninsula, northern Honshu, and to the north and east of Kushiro, Hokkaido. Considering its present distribution, shell sizes, and abundance, it is most likely that it was introduced into 3 separate port areas in NE Honshu, Japan, during the last 20 to $40 \mathrm{yr}$, probably by anthropogenic activities. It was apparently also introduced to the La Plata estuary, Argentina, during the same period. B. glandula is becoming a dominant littoral zone species, especially in embayments, largely at the expense of the tropical endemic $B$. albicostatus in the upper littoral fringe. Taking into account the biogeographical distribution of common Japanese barnacles in relation to water temperature, the future distribution of the newly introduced species is considered.
\end{abstract}

KEY WORDS: Balanus glandula Introduced species · Distribution · Annual mean water temperature · Biogeography $\cdot$ Anthropogenic activities

\section{INTRODUCTION}

The introduction of marine organisms around the world by ocean-going ships has affected domestic biotas mainly in competition for food and space. The arrival of the Australasian barnacle Elminius modestus Darwin to Europe is the first well documented transoceanic barnacle invasion (Bishop 1947, Crisp \& Chipperfield 1948, Stubbings 1950, Crisp 1958). A more recent example of transoceanic spread is the invasion of Hawaiian shores by the western Atlantic species Chthamalus proteus (Southward et al. 1998). Earlier, Balanus eburneus Darwin, common along the east coast of North America, had been introduced to Rochelle, France, by shipping (Pilsbry 1916). Although E. modestus has not yet been found in Japanese waters, B. eburneus has appeared during the last $50 \mathrm{yr}$, as well as B. improvisus Darwin, which is common along estuaries in western Europe. The latter 2 warmwater species were first recorded in central Japan, but are now found throughout Japan (except Hokkaido), where they are dominant forms in embayments (Kawahara 1963, Utinomi 1966, Yamaguchi 1977, 1989).

On the NE coast of Honshu, the endemic littoral barnacle fauna includes Semibalanus cariosus, Chthamalus dalli, C. challengeri, Tetraclita japonica, Balanus albicostatus, and Capitulum mitella. Of these, S. cariosus and Chthalmus dalli are the only cold-water species. No introduced barnacles have been known to inhabit the littoral zone in northern Japan. In May 2000, however, we found an abundant but hitherto unknown (in this area) barnacle, B. glandula Darwin, 1854 in this habitat (Ofunato Bay, Iwate Prefecture; see Stn 24 in Table 1).

Balanus glandula is a common cold-water littoral barnacle along the western coast of North America 
(Pilsbry 1916, Henry 1942, Newman \& Abbott 1980, Foster et al. 1991). Darwin (1854) noted that it ranged from the northern Pacific to California, i.e. from the Aleutians (Bering Sea) to Baja California (Newman \& Ross 1976). While this species has not previously been recorded from the eastern side of Asia, it was recently reported to be established in Mar del Plata, Argentina (Young 1995, Vallarino \& Elias 1997).

Following the discovery of Balanus glandula (Fig. 1) in Japan in 2000, several surveys were conducted along the northern coast to clarify the actuality of its invasion. The present work reports on its distribution and abundance and its ecological and biogeographical relationships with the endemic barnacles; the time and the route of the introduction is also discussed.
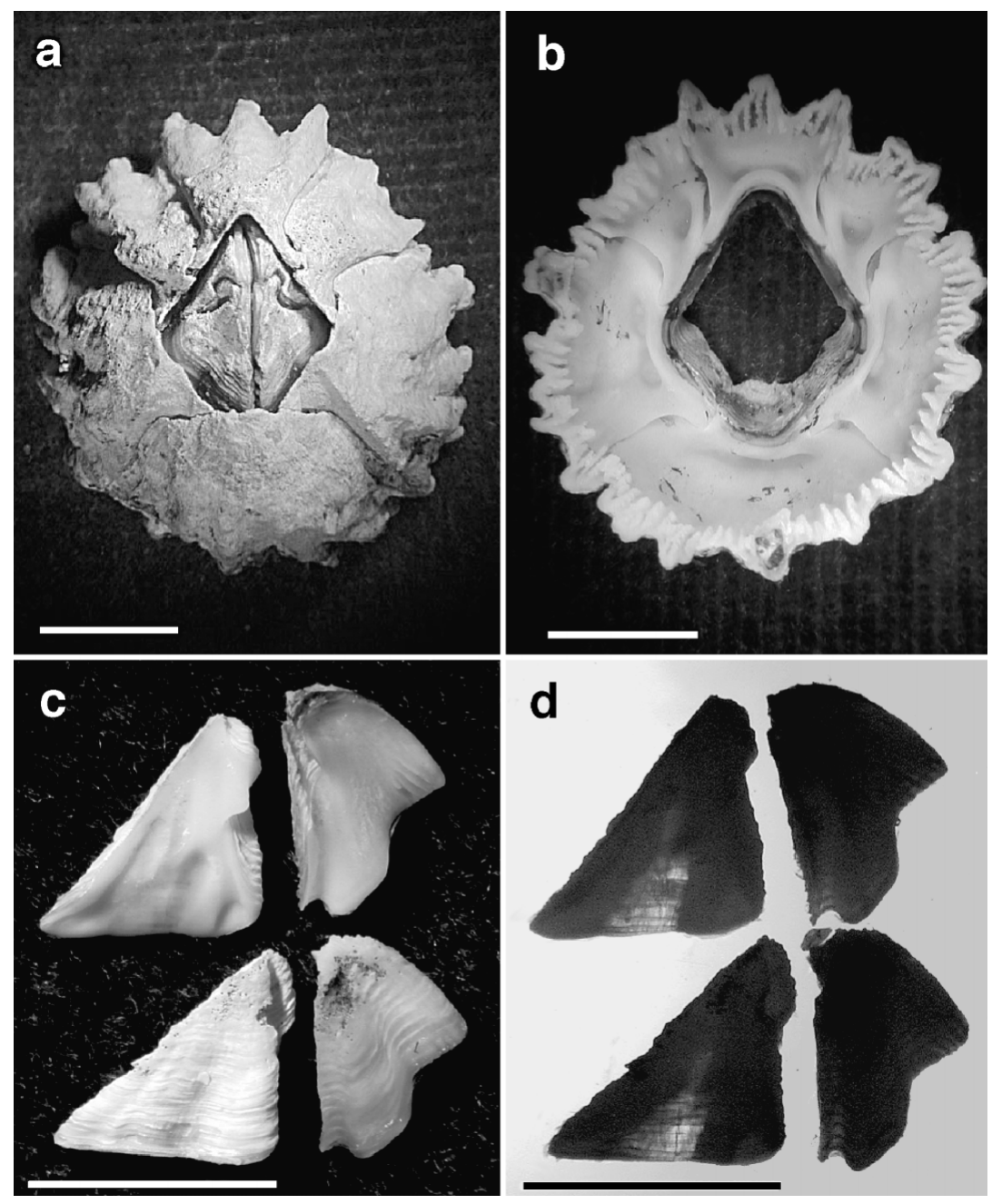

Fig. 1. Balanus glandula from Orikasa, Yamada Bay, Iwate Prefecture. External and internal view of (a), (b) parietes and (c) valves. (d) Translucent central portion of scutum viewed with transmitted light. Scale bars $=5 \mathrm{~mm}$

\section{MATERIALS AND METHODS}

Ecological surveys of the littoral zone were conducted along the coast of northern Japan from June to August $2000\left(39^{\circ} 50^{\prime} \mathrm{N}\right.$ along the coast of the Sea of Japan, and north of $38^{\circ} 20^{\prime} \mathrm{N}$ along the coast of the Pacific Ocean and the Sea of Okhotsk). About 50 fishing ports with concrete mooring slopes and adjacent quay walls were selected as survey stations because of ease of access and uniformity of the substratum, i.e. concrete.

To assess the present extent of the invasion by Balanus glandula, at each site a sampling location with a high population density of $B$. glandula was selected, regardless of shell size and age. Using 1 of 4 quadrats $(5 \times 5,10 \times 10,25 \times 25,100 \times 100 \mathrm{~cm})$, depending on the visually estimated density, the density of B. glandula at each sampling site was measured 2 or 3 times, and the maximum value recorded. Population zone width and height above mean sea level were also investigated at each station at low tide. Minimum brooding size was examined for about 20 individuals $<8 \mathrm{~mm}$ in diameter at each site by noting the presence of brooding embryos inside the mantle cavity. As an indicator of reproductive potential of this species, the possibility of self-fertilization was checked by comparing a population of 24 solitary settled individuals (>10 cm apart) with a population of 104 gregariously settled individuals, by examining specimens with $>7.8 \mathrm{~mm}$ rostro-carinal diameter at Shimanokoshi (Fig. 2, Stn 14) on 20 June 2000.

\section{RESULTS}

Balanus glandula was found at most stations on the Pacific side of Japan, north of Aikawa, from Oppa Bay (Fig. 2: Stn 29) to Hokkaido (Stn 41). Densities at stations where the barnacle occurred varied from $1 \mathrm{~m}^{-2}$ (Shinhama, Kamaishi Bay) to $40000 \mathrm{~m}^{-2}$ (Tamanowaki, Kuji Bay) (Table 1). At Tamanowaki (Fig. 2: Stn 13), rock surfaces adjacent to concrete mooring slopes were almost completely covered by this species, which occurred there in 3 size classes ( 2 to 3,7 to 8,12 to $13 \mathrm{~mm}$ : Fig. 3). The largest individual was found at Orikasa, Iwate Prefecture 
(Fig. 2: Stn 16) and was $22.7 \mathrm{~mm}$ in rostro-carinal diameter. B. glandula was not detected in Sakihama, Okkirai Bay (Fig. 2: Stn 22), located 13 km NE of Kamihira or Sasazaki, Ofunato Bay (Fig. 2: Stn 24), but was abundant $6 \mathrm{~km}$ south of Konpaku, Yoshihama Bay (Fig. 2: Stn 21).

No Balanus glandula were detected at stations along the Honshu coast facing the Sea of Japan, but the south and west coast of Hokkaido have yet to be surveyed.

Balanus glandula tends to occur between the mean high-water spring and extreme low-water spring tides, depending on the degree of exposure and the presence of other organisms (Fig. 4). It generally occurs together with at least 1 of 4 endemic barnacles: Chthamalus (i.e. C. challengeri and/or C. dalli), Semibalanus cariosus, and B. albicostatus (Fig. 4). The first 3 of these species were common at stations close to the open sea. B. glandula overlapped with both Chthamalus spp., which usually occur on higher levels of the shore, and with $S$. cariosus, which is always found on lower levels. On the other hand, $B$. albicostatus was the only barnacle occurring together with B. glandula in the littoral zone in semi-enclosed bays such as Ofunato (Fig. 2: Stn 24) and Yamada Bay (Fig. 2: Stn 16). The density of $B$. albicostatus was not high in comparison with that of the other barnacles in the same area. $B$. amphitrite also occurred in Ofunato Bay, but was uncommon. B. glandula at these stations exceeded B. albicostatus in abundance, but did not range as high into the intertidal. Where the 4 barnacles co-occurred, as at Akahama (Fig. 2: Stn 17) and Tarou (Fig. 2: Stn 15), they were generally distributed, from the top to the bottom of the shore, in the order C. challengeri, B. albicostatus, B. glandula, and S. cariosus. East of Tomakomai (Fig. 2: Stn 38), especially at Hiroo (Fig. 2: Stn 41), C. dalli dominated the upper to middle littoral zone, where it settled heavily in late July and early August of 2000, apparently to the detriment of B. glandula (these 2 species as well as $S$. cariosus co-occur naturally along the Pacific coast of North America).

At the stations with no Balanus glandula, the littoral habitats were dominated by Chthamalus challengeri (Honshu) or C. dalli (Hokkaido) in the upper and middle zones or by $B$. albicostatus in sheltered harbor areas (Honshu only) in these zones, and by Semibalanus cariosus in the lower zone. S. cariosus in Okkirai Bay has decreased remarkably in biomass over the past $4 \mathrm{yr}$, while biomass of the oyster Crassostrea gigas has increased (R. Kado unpubl. data).

The minimum reproductive size of Balanus glandula was $5.8 \mathrm{~mm}$ carino-lateral diameter. None of the 24 solitary settled individuals was brooding embryos, while $30 \%$ of the gregariously settled individuals were brooding.

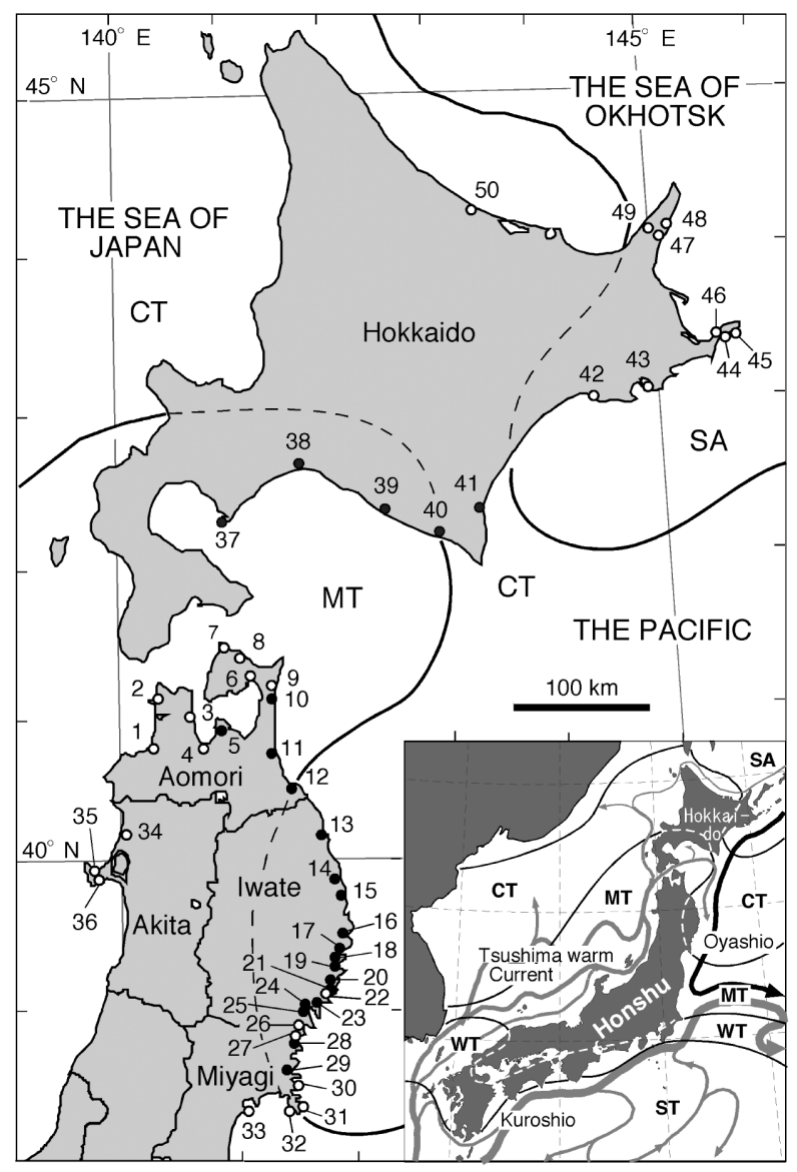

Fig. 2. Balanus glandula. Distribution in northern Japan. $(\circ, \bullet)$ Stations at which $B$. glandula has not been or has been detected, respectively. Numbers indicate stations surveyed (Table 1). Inset illustrates major currents and climatic zones: ST: subtropical; WT: warm-temperate; MT: mid-temperate; CT: cold-temperate; SA: subarctic (after Nishimura 1981, 1992)

\section{DISCUSSION}

In spite of its abundance, the reason the newly discovered Balanus glandula was apparently overlooked for a number of years may be as follows: (1) the shape and color of B. glandula and Semibalanus cariosus are similar (both dirty white), although the latter does not occur above high tide; (2) a gradual increase in recruits of B. glandula to the high intertidal was probably mistaken as an increase in $S$. cariosus where $S$. cariosus was dominant. In quiet waters, $S$. carious is very rare, however, and the endemic barnacle $B$. albicostatus is found from the upper to the lower part of the littoral zone (Yamaguchi 1977). B. albicostatus has white narrow ribs on a dark purple shell. Therefore, unless observed closely the 2 species look similar when the shells are dirty or covered with algae. Thus, B. glandula became well established in the littoral zone of many harbors before it was discovered in NE Japan. 
Table 1. Balanus glandula. Occurrence and density at stations surveyed on Pacific, Sea of Japan, and Sea of Okhotsk coasts of northern Japan in 2000. Associated barnacles are also listed. Station locations shown in Fig. 2. Nearby locations are not numbered; N: undetected, R: rare, F: frequent, A: abundant; ne: not closely examined; Bc: Balanus crenatus, Be: B. eburneus, Bi: B. improvisus, Bm: B. amphitrite, Bl: B. albicostatus, CC: Chthamalus challengeri, Cd: Chthamalus dalli, SC: Semibalanus cariosus

\begin{tabular}{|c|c|c|c|c|c|c|}
\hline Station & Stn no. & Abundance & Max. density (ind. $\mathrm{m}^{-2}$ ) & Size $(\mathrm{mm})$ & Other barnacles & Date \\
\hline \multicolumn{7}{|l|}{ Aomori Prefecture } \\
\hline Ajigasawa & 1 & $\mathrm{~N}$ & - & - & $B m$ & Jul 5 \\
\hline Kodomari & 2 & $\mathrm{~N}$ & - & - & $C_{C}$ & Jul 5 \\
\hline Gousawa & 3 & $\mathrm{~N}$ & - & - & $C_{C}, B l, S c$ & Jul 5 \\
\hline Aomori & 4 & $\mathrm{~N}$ & - & - & $\mathrm{CC}_{\mathrm{I}} \mathrm{SC}_{\mathrm{C}}$ & Jul 4 \\
\hline Asadokoro & 5 & $\mathrm{~N}$ & - & - & $\mathrm{CC}_{\mathrm{C}} \mathrm{Bl}$ & Jul 4 \\
\hline Moura & & $\mathrm{R}$ & 2 & $6-9.5,11-12.5$ & $\mathrm{CC}_{\mathrm{C}} \mathrm{Bl}$ & Jul 4 \\
\hline Oominato & 6 & $\mathrm{~N}$ & - & - & $C_{C}, B l, S c$ & Jul 3 \\
\hline Ooma & 7 & $\mathrm{~N}$ & - & - & $\mathrm{CC}_{\mathrm{C}}$ & Jul 3 \\
\hline Shitafuro & 8 & $\mathrm{~N}$ & - & - & $C_{C}, S C$ & Jul 3 \\
\hline Odanozawa & 9 & $\mathrm{~N}$ & - & - & $\mathrm{CC}_{\mathrm{C}}$ & Jul 3 \\
\hline Shiranuka & 10 & $\mathrm{~F}$ & 500 & $2-3,15-18$ & $C_{C}, B l, S C$ & Jul 3 \\
\hline Misawa & 11 & $\mathrm{~A}$ & 1000 & $4-6,11-12$ & $C_{C}, B l$ & Jul 2 \\
\hline Kofunatodaira & 12 & $\mathrm{~A}$ & 2000 & $2-5,9-12$ & $\mathrm{CC}$ & Jul 2 \\
\hline \multicolumn{7}{|l|}{ Iwate Prefecture } \\
\hline Tamanowaki & 13 & A & 40000 & $2-3,7-8,12-13$ & $C_{C}, B l, S_{C}$ & Jul 2 \\
\hline Hiraiga & 14 & A & 10000 & ne & $\mathrm{CC}_{\mathrm{I}} \mathrm{SC}$ & Jul 2 \\
\hline Shimanokoshi & & $\mathrm{A}$ & 3200 & ne & $\mathrm{CC}_{\mathrm{I}} \mathrm{SC}_{C}$ & Jun 20 \\
\hline Tarou & 15 & $\mathrm{~A}$ & 4000 & ne & $C_{C}, S_{C}$ & Jun 20 \\
\hline Orikasa & 16 & A & 3300 & $3-8 / 10-16$ & $B l$ & Jul 20 \\
\hline Akahama & 17 & $\mathrm{~F}$ & 384 & ne & $B l, S C$ & Jun 19 \\
\hline Ryoishi & 18 & $\mathrm{~A}$ & 1700 & $5-8,11-15$ & $B l, S C$ & Jun 19 \\
\hline Shinhama & 19 & $\mathrm{R}$ & 1 & 8,11 & $C_{C}, B l, S C$ & Jun 19 \\
\hline Touni & 20 & $\mathrm{~F}$ & 112 & ne & $C_{C}, B l, S C$ & Jun 19 \\
\hline Konpaku & 21 & $\mathrm{~F}$ & 200 & $6-8,11-15$ & $C_{C}, S_{C}$ & Jun 17 \\
\hline Sakihama & 22 & $\mathrm{~N}$ & - & - & $C_{C}, B l, S C$ & Jun 3 \\
\hline Urahama & & $\mathrm{R}$ & 16 & ne & $C_{C}, B l, S C$ & Jun 17 \\
\hline Nonomae & & $\mathrm{N}$ & - & - & $C_{C}, B l, S C$ & Jun 3 \\
\hline Tahama & 23 & $\mathrm{R}$ & 300 & ne & $C_{C}, B l, S C$ & Jun 3 \\
\hline Nagasaki & & $\mathrm{F}$ & 128 & ne & $C_{C}, S_{C}$ & Jun 3 \\
\hline Sasazaki & 24 & $\mathrm{~A}$ & 10000 & ne & Bl & Jun 2 \\
\hline Kamihira & & $\mathrm{A}$ & 8000 & $3-11,13-16$ & $B l, B m$ & Jun 4 \\
\hline Kadonohama & & $\mathrm{F}$ & 200 & ne & $C_{C}, S_{C}$ & Jun 4 \\
\hline Kyumikkaichi & & $\mathrm{R}$ & 1 & $14-15$ & $\mathrm{CC}_{\mathrm{C}} \mathrm{Bl}$ & Jun 4 \\
\hline Takata-Matsubara & 25 & $\mathrm{R}$ & 1 & $12-17$ & $S_{C}, B l$ & Jun 4 \\
\hline \multicolumn{7}{|l|}{ Miyagi Prefecture } \\
\hline Tadakoe & & $\mathrm{R}$ & 2 & ne & $C_{C}, S_{C}$ & Jun 18 \\
\hline Ooura & 26 & $\mathrm{~N}$ & - & - & $\mathrm{CC}_{\mathrm{C}} \mathrm{Bl}$ & Jun 18 \\
\hline Ninoura & & $\mathrm{N}$ & - & - & $\mathrm{CC}_{\mathrm{C}} \mathrm{Bl}$ & Jun 18 \\
\hline Amagasawa & 27 & $\mathrm{~N}$ & - & - & CC & Jul17 \\
\hline Nijuuichihama & 28 & $\mathrm{R}$ & $<1$ & $6-13$ & $C_{C}, B l, S C$ & Jul 17 \\
\hline Aikawa & 29 & $\mathrm{R}$ & $<1$ & $8-13$ & $C_{C}, B l, S C$ & Jul 17 \\
\hline Oura & 30 & $\mathrm{~N}$ & - & - & $C_{C}, B l, S C$ & Jul 17 \\
\hline Yagawa & 31 & $\mathrm{~N}$ & - & - & $C_{C}, B l, S c$ & Jul 18 \\
\hline Oohara & 32 & $\mathrm{~N}$ & - & - & $\mathrm{CC}_{\mathrm{B}} \mathrm{Bl}$ & Jul 18 \\
\hline Shoubutahama & 33 & $\mathrm{~N}$ & - & - & $\mathrm{CC}_{\mathrm{r}} \mathrm{Bl}$ & Jul 18 \\
\hline \multicolumn{7}{|l|}{ Akita Prefecture } \\
\hline Noshiro & 34 & $\mathrm{~N}$ & - & - & $B l, B e, B i, B m$ & Aug 6 \\
\hline Kitaura & 35 & $\mathrm{~N}$ & - & - & $\mathrm{Cc}, \mathrm{Bm}$ & Aug 6 \\
\hline Funakawa & 36 & $\mathrm{~N}$ & - & - & $\mathrm{CC}_{\mathrm{r}} \mathrm{Bm}$ & Aug 6 \\
\hline \multicolumn{7}{|l|}{ Hokkaido } \\
\hline Muroran & 37 & A & 8000 & ne & $C_{C}, S C$ & Jul 31 \\
\hline Tomakomai & 38 & A & 16000 & ne & $C d, S_{C}$ & Jul 31 \\
\hline Shizunai & 39 & $\mathrm{~F}$ & 500 & ne & $\mathrm{CC}_{\mathrm{l}}, \mathrm{Cd}, \mathrm{Sc}$ & Jul 31 \\
\hline Urakawa & 40 & $\mathrm{~F}$ & 300 & ne & $C d, S_{C}$ & Aug 1 \\
\hline Hiroo & 41 & $\mathrm{~F}$ & 300 & ne & $\mathrm{Cd}, \mathrm{SC}_{\mathrm{C}}$ & Aug 1 \\
\hline Katsurakoi & 42 & $\mathrm{~N}$ & - & - & $\mathrm{Cd}$ & Aug 2 \\
\hline Akkeshi & 43 & $\mathrm{~N}$ & - & - & $C d$ & Aug 2 \\
\hline Tokotan & & $\mathrm{N}$ & - & - & $C d, S c$ & Aug 2 \\
\hline Tomoshiri & 44 & $\mathrm{~N}$ & - & - & $C d, S c$ & Aug 2 \\
\hline Oineppu & & $\mathrm{N}$ & - & - & $C d, S C$ & Aug 2 \\
\hline Habomai & 45 & $\mathrm{~N}$ & - & - & $C d, S c$ & Aug 3 \\
\hline Nemuro & 46 & $\mathrm{~N}$ & - & - & $C d, S c$ & Aug 3 \\
\hline Rausu & 47 & $\mathrm{~N}$ & - & - & $C d, \mathrm{Bc}_{1} S_{C}$ & Aug 4 \\
\hline Chienbetsu & 48 & $\mathrm{~N}$ & - & - & $C d, \mathrm{Bc}, S_{C}$ & Aug 4 \\
\hline Utoro & 49 & $\mathrm{~N}$ & - & - & $C d, S_{C}$ & Aug 4 \\
\hline Monbetsu & 50 & $\mathrm{~N}$ & - & - & $C d, S c$ & Aug 5 \\
\hline Saruru & & $\mathrm{N}$ & - & - & $C d, S c$ & Aug 5 \\
\hline
\end{tabular}




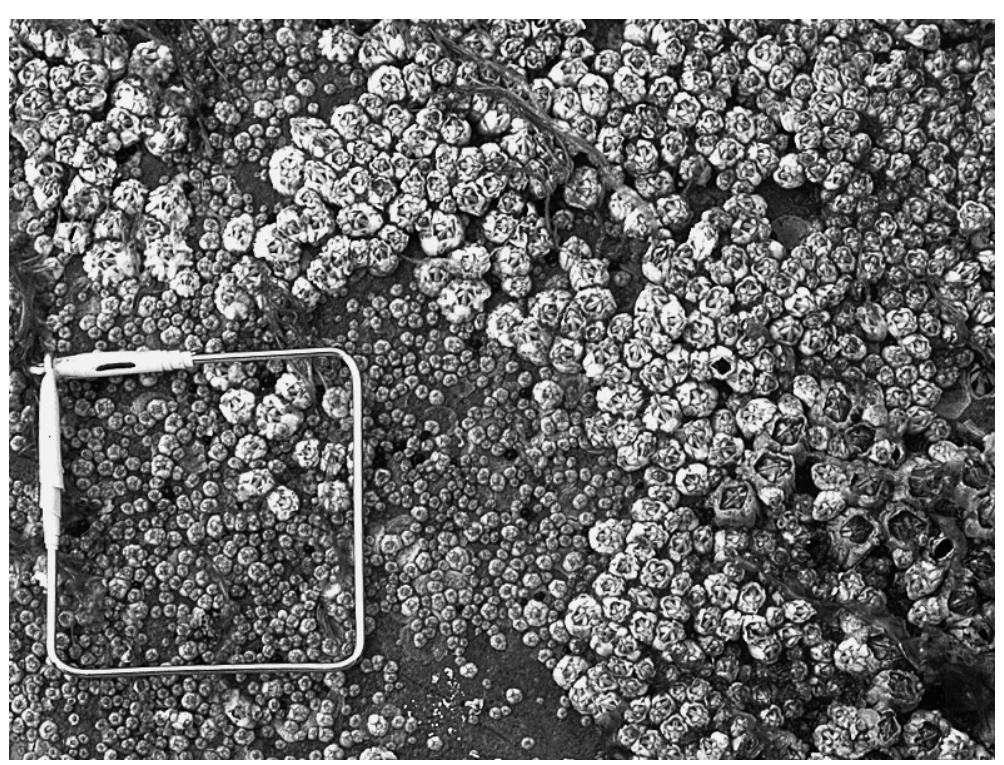

Fig. 3. Balanus glandula on rock surface at Tamanowaki, Kuji Bay, Iwate Prefecture. Three size classes were observed: 2 to $3 \mathrm{~mm}$ (lower left), 7 to $8 \mathrm{~mm}$ (top), 12 to $13 \mathrm{~mm}$ (lower right). The quadrat on the lower left is $5 \mathrm{~cm}$ square

\section{Relationship with endemic species}

The vertical distributions of the endemic barnacles encountered in this survey are comparable to those in previous reports (Hiro 1938, Hoshiai 1965, Yamaguchi 1977). As shown in Fig. 4, Balanus glandula has invaded the habitats of Chthamalus challengeri and/or C. dalli and B. albicostatus, as well as that of Semibalanus cariosus. Because of its relatively low density, $B$. albicostatus, one of the commonest temperate to subtropical barnacles, is apparently suffering the greatest impact from B. glandula, especially in sheltered waters such as Ofunato Bay, where the open-coast species $S$. cariosus and C. challengeri are rare. $B$. albicostatus is free from competition only at the upper fringe of the zone. $B$. glandula apparently dominates $B$. albicostatus because it can breed at a small size ( $6 \mathrm{~mm}$ rostro-carinal diameter) and settles from early spring to early summer in high densities (Barnes \& Barnes 1956, Hines 1978, R. Kado unpubl. data). It therefore becomes established in available open spaces before $B$. albicostatus recruits arrive. This is probably one of the reasons why $B$. glandula succeeded in becoming established in this region.
Self-fertilization does not seem to occur in Balanus glandula, as indicated by the absence of solitary individuals, and therefore solitary brooding individuals do not contribute to its breeding population. In other words, it is essential for the species to be dense enough to ensure crossfertilization in order to reproduce. This means that it might require a longer period to extend its distribution than species with the ability to self-fertilize. Chthamalines have a higher settlement zone than $B$. glandula (Hines 1978), so they can maintain populations despite B. glandula cooccupying the lower part of their range. Semibalanus cariosus is also subject to competition from $B$. glandula, but not as seriously as $B$. albicostatus because of its wider settlement zone, which extends into the sublittoral. In North America, Mytilus californianus is the best competitor for space, followed by $S$. cariosus, Chthamalus dalli, and seaweeds in that order (Dayton 1971). S. cariosus and the chthamalines display a similar pattern in Japan. In the lower littoral zone, the mussels M. galloprovincialis and/or Septifer virgatus and the oyster Crassostrea gigas compete for space with Semibalanus cariosus. Therefore, they are also likely to be in competition with B. glandula. Since B. glandula frequently

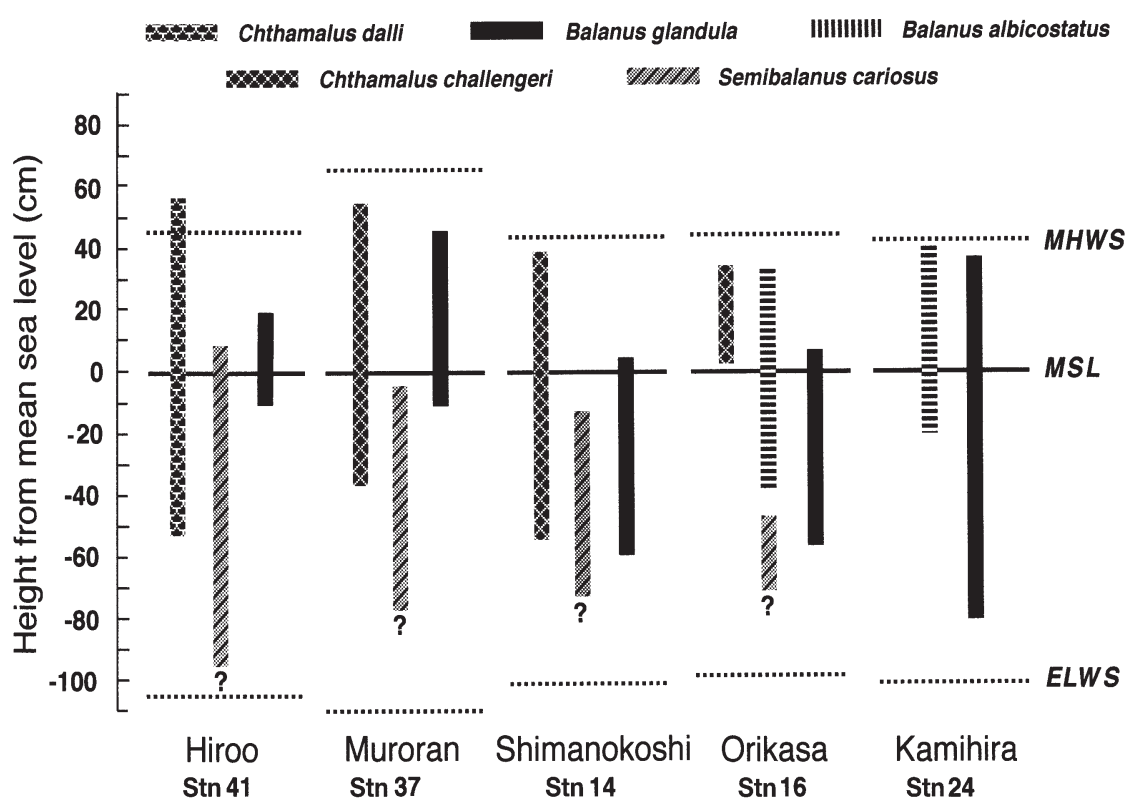

Fig. 4. Zonation of barnacles (including Balanus glandula) at 5 locations in northern Japan. Question marks indicate that lower limit of the species was not determined. Station numbers as in Table 1 \& Fig. 2. MHWS: mean high-water spring tide; MSL: mean sea level; ELWS: extreme low-water spring tide 
uses mussels as substrate, it would seem to be much more facultative than $S$. cariosus, which is rarely found on mussels.

\section{Biogeography}

On the Pacific coast of North America, Balanus glandula ranges through the Californian, Oregonian and Aleutian faunal provinces (warm temperate to subarctic regions), but is also present along the Pacific coast of Russia. The southern limit $\left(30^{\circ} 30^{\prime} \mathrm{N}\right)$ of the species is in Baja California, at the transition zone between the Californian (warm temperate region) and Panamic (tropical/subtropical region) faunal provinces (Laguna 1990).

The annual mean water temperature at its southern limit is around $17^{\circ} \mathrm{C}$ (see Fig. 5 in Newman 1979), and the mean temperature in summer does not exceed $22^{\circ} \mathrm{C}$ (Chronological Scientific Tables 2001). Seasonal water temperatures near the outfall of a power plant in Morro Bay, California $\left(35^{\circ} 22^{\prime} 30^{\prime \prime} \mathrm{N}\right)$ fluctuates between $14^{\circ} \mathrm{C}$ in April and $30^{\circ} \mathrm{C}$ in September. Under such warm conditions, Balanus glandula is restricted to breeding between December or February and May, when the weekly mean water temperature ranges from 17 to $20 / 21^{\circ} \mathrm{C}$ (Hines 1978).

On the coasts of Japan, near $36^{\circ} \mathrm{N}$ (at the southern end of the mid-temperate [Nishimura 1981] region on the Pacific coast), and between 36 and $38^{\circ} \mathrm{N}$ (30' north of the mid-temperate region on the coast of the Sea of Japan), annual mean water temperature is about $17^{\circ} \mathrm{C}$ (Fig. 5). Water temperature fluctuations at both ends of the mid-temperate region are between 11 and $23^{\circ} \mathrm{C}$ on the Pacific coast, and between 11 and $27^{\circ} \mathrm{C}$ on the Sea of Japan coast (Geological Survey of Hokkaido 1996-1999).

The southern limit of another cold-temperate littoral barnacle, Semibalanus cariosus, is Cape Inubo $\left(35^{\circ} 43^{\prime} \mathrm{N}\right)$, at the southern end of the mid-temperate region on the Pacific coast (Yamaguchi 1987), whereas on the Sea of Japan coast it is around $41^{\circ} \mathrm{N}$ (Utinomi 1955) (Fig. 5). The southern limit of this species on the Pacific coast of North America is $37^{\circ} \mathrm{N}$ (Newman 1979), $6^{\circ} 30^{\prime}$ north of the southern limit for Balanus glandula.

In view of the distribution of Semibalanus cariosus and the fact that Balanus glandula at Morro Bay bred at temperatures below $22^{\circ} \mathrm{C}$ (Hines 1978), this barnacle should be able to breed in the mid-temperate region on the Pacific coast of Japan. However, it is not likely that $B$. glandula will extend its distribution to the midtemperate region along the coast of the Sea of Japan because of the high summer water temperatures there (Geological Survey of Hokkaido 1996-1999). On the other hand, the sub-arctic/cold-temperate barnacle
Chthamalus dalli is distributed throughout in the North Pacific Province and co-occurs with B. glandula along the west coast of North America. This suggests that $B$. glandula may migrate further east along Hokkaido, and perhaps along the west coast of the North Pacific, where this species has not yet been found (Zvyagintsev 2000).

A similar biogeographical situation prevails in Argentina on the Atlantic side of South America, where introduced Balanus glandula have not expanded their range north or south of the transition zone where the warm Brazilian and cold Falkland currents mix (Young 1995). In Argentina, the species overwhelmingly dominates the mid-littoral zone at 2 to 3 times higher densities than in North America (Vallarino \& Elias 1997).

\section{Time and route of invasion}

Although the growth rate of Balanus glandula in Japan waters is not known, the largest individual had a rostoro-carinal diameter of $22.7 \mathrm{~cm}$. Applying the growth rate calculation of Barnes \& Barnes (1956) and Hines (1978) for North America, it might therefore have been more than 8 yr old.

Two possibilities have been considered to account for the origin of Balanus glandula in Japan: (1) an

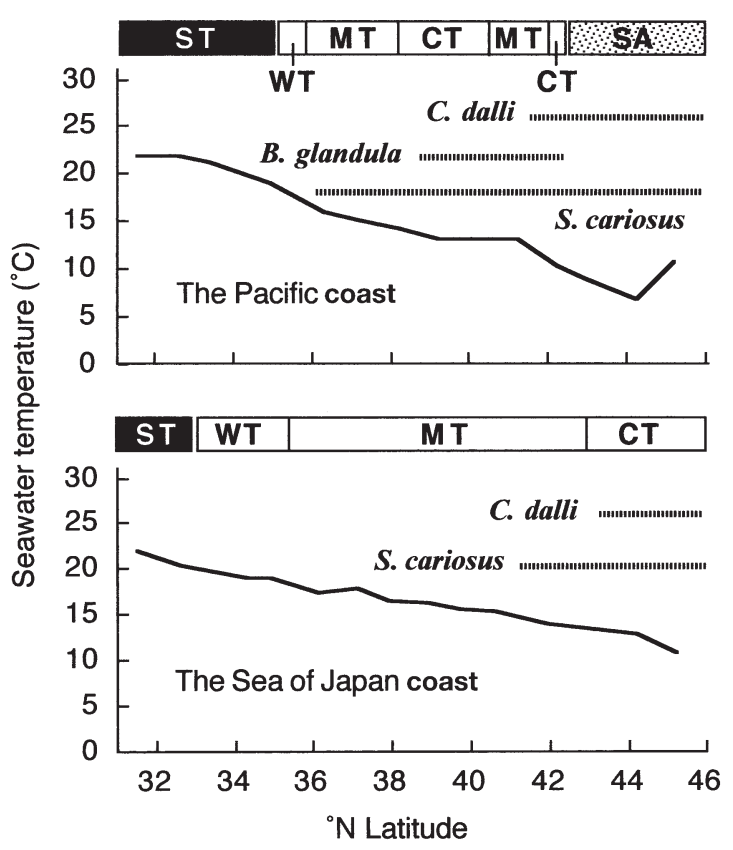

Fig. 5. Long-term temperature means (Aomori Prefectural Fisheries Experimental Station 1985-2000, Geological Survey of Hokkaido 1996-1999) along Pacific and Sea of Japan coasts of Japan. Latitudinal distributions of Balanus glandula, Chthamalus challengeri, and Semibalanus cariosus are shown. Abbreviations as in Fig. 2 
extension of its normal distribution by larval dispersal along the shores of the Aleutians, the Kamchatka Peninsula, and the Kuril Islands, or (2) transport by ocean-going ships. The first possibility is considered unlikely because the species has not been found on the east coast of Hokkaido (Pacific and Sea of Okhotsk coasts) or in the Far East region of Russia, from where there are no reports for this species except in the Bering Sea region (Hiro 1935, Zevina 1980, Zvyagintsev 2000).

The second possibility seems more likely in view of the following circumstantial evidence. According to the records of the harbor customs offices along the north-east coast of Japan, timber has been imported on the decks of ships to Sasazaki, Ofunato Bay (Table 1: Stn 24), Hachinohe (Table 1: Stn 12) and Tomakomai (Table 1: Stn 38) in northern Japan since the 1960s from many ports such as Vancouver, Seattle, Tacoma, and Klawak etc. along the Pacific coast of North America. As a result, larvae released from fouling organisms may have settled and become established at one or more of the Japanese ports of arrival. The distribution data show that population density declines with increasing distance from these ports. For example, density (Fig. 6) is highest at Stns 13, 24 and 38, each of which is either a timberimporting port itself or close to such a port (Fig. 6). This suggests that this species has at least 3 population centers and that its introduction occurred on separate occasions. Considering that Balanus glandula was introduced to La Plata estuary, Argentina, despite the great thermal change it encountered when passing through the tropics (Young 1995), the moderate temperature changes across the northern Pacific are not likely to constitute a barrier to its importation by ships. If such importation has occurred, then it constitutes a further case of westward transport across the ocean by anthropogenic activities. It follows the invasion of Hawaiian shores by the Atlantic barnacle Chthamalus proteus (Southward et al. 1998), which also succeeded in occupying a largely vacant niche in the upper mid-littoral zone of sheltered Hawaiian shores.

The literature for Otsuchi Bay (Akahama: Table 1 \& Fig. 2: Stn 17), which has the most thoroughly investigated marine biota on the NE coast of Japan, includes no reports of Balanus glandula, either living (Kajihara \& Ura 1976, Kado et al. 1980) or in the sediments (E. Honza \& T. Igarashi unpubl.). Therefore, in Otsuchi Bay, it appears that B. glandula was introduced less than 20 yr ago. In other areas of northern Honshu, for which few published faunal surveys exist, B. glandula may have been introduced within the past $40 \mathrm{yr}$, i.e. since the beginning of intensive trading in the 1960s.

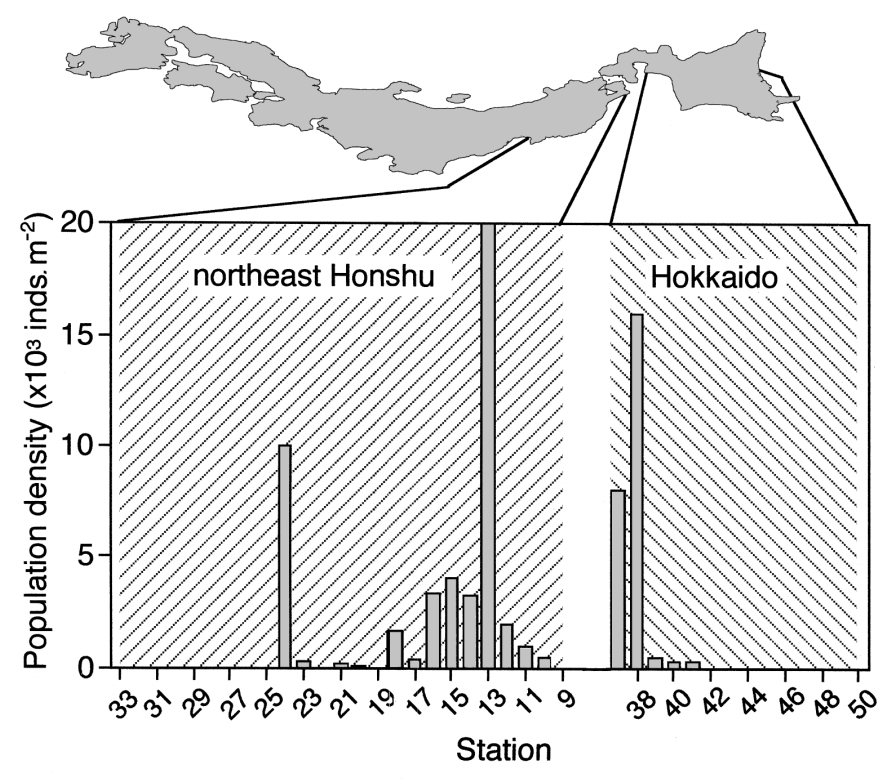

Fig. 6. Balanus glandula. Maximum population density at stations surveyed on Pacific coast of northern Japan. Station numbers as in Table 1 \& Fig. 2

Acknowledgements. I express my sincere thanks to Professor William A. Newman, Scripps Institution of Oceanography, La Jolla, California, for reading the manuscript and making many helpful comments, especially regarding the biogeography involved. I also thank Professor Toshiyuki Yamaguchi, Faculty of Science, Chiba University, for identification, advice in selecting the Japanese name 'Kita-Amerika fujitsubo' (meaning North American barnacle) for Balanus glandula, for lending literature on it, and for biogeographical comments on Japan.

\section{LITERATURE CITED}

Aomori Prefectural Fisheries Experimental Station (19852000) 'UODAS' (Usable to Offshore-fisheries Data Acquisition System)-the results of fisheries oceanographical observation. UODAS Gyokaikyo Sokuho, 1-1120 (in Japanese)

Barnes H, Barnes M (1956) The general biology of Balanus glandula Darwin. Pac Sci 10:415-422

Bishop MWH (1947) Establishment of an immigrant barnacle in British coastal waters. Nature 159:501

Chronological Scientific Tables (2001) National Astronomical Observatory (ed), Maruzen, Tokyo

Crisp DJ (1958) The spread of Elminius modestus Darwin in northwest Europe. J Mar Biol Assoc UK 37:483-520

Crisp DJ, Chipperfield PN (1948) Occurrence of Elminius modestus (Darwin) in British waters. Nature 161:64

Darwin C (1854) A monograph on the sub-class Cirripedia. The Balanidae etc. Ray Society, London

Dayton PK (1971) Composition disturbance and community organization: the provision and subsequent utilization of space in a rocky intertidal community. Ecol Monogr 41: 351-389

Foster MS, De Vogelaere AP, Oliver JS, Pearse JS, Harrold C (1991) Open coast intertidal and shallow subtidal ecosys- 
tems of the northeast Pacific. In: Mathieson AC, Nienhuis $\mathrm{PH}$ (eds) Intertidal and littoral ecosystems. Elsevier, New York, p 235-272

Geological Survey of Hokkaido (1996-1999) Data record of coastal water temperatures in Japan - ten day means of month in 1994-1998 Nos. 1-5, Geological Survey of Hokkaido, Sapporo

Henry DP (1942) Studies on the sessile Cirripedia of the Pacific coast of North America. Univ Wash Publ Oceanogr 4:95-134

Hines AH (1978) Reproduction in three species of intertidal barnacles from central California. Biol Bull 154:202-281

Hiro F (1935) The fauna of Akkeshi Bay. II. Cirripedia. J Fac Sci Hokkaido Univ Ser VI Zool 4:213-229

Hiro F (1938) On the Japanese forms of Balanus amphitrite Darwin. Zool Mag 50:299-313 (in Japanese with English figure legends)

Hoshiai T (1965) Synecological study on intertidal communities. VI. A synecological study on the intertidal zonation of the Asamushi coastal area with special reference to its reformation. Bull Mar Biol Stn Asamushi 12:93-126

Kado R, Hino A, Hirano R (1980) Barnacles (Cirripedia, Thoracica) in Otsuchi Bay, breeding and settling seasons of boreo-arctic and warm water species. Rep Otsuchi Mar Res Cent Jpn 7:7-12 (in Japanese)

Kajihara T, Ura Y (1976) Attaching animals in Otsuchi. Rep Otsuchi Mar Res Cent Jpn 2:20-29 (in Japanese)

Kawahara T (1963) Invasion into Japanese waters by the European barnacle Balanus improvisus Darwin. Nature 4877:301

Laguna JE (1990) Shore barnacles (Cirripedia, Thoracica) and a revision of their provincialism and transition zones in the tropical eastern Pacific. Bull Mar Sci 46:406-424

Newman WA (1979) Californian transition zone: significance of short-range endemics: In: Gray J, Boucot AJ (eds) Historical biogeography, plate tectonics, and the changing environment. The Oregon State University Press, Corvallis, p 399-416

Newman WA, Abbott DP (1980) Cirripedia: the barnacles. In: Morris H, Abbott DP, Haderlie EC (eds) Intertidal invertebrates of California. Stanford University Press, Stanford, CA, p 504-535

Newman WA, Ross A (1976) Revision of the balanomorph barnacles, including a catalog of the species. Mem S Diego Soc Nat Hist 9:1-108

Editorial responsibility: Otto Kinne (Editor), Oldendorf/Luhe, Germany
Nishimura S (1981) Seas and life on the Earth. Kaimeisha, Tokyo (in Japanese)

Nishimura S (1992) Compendium: In: Nishimura S (ed) Guide to seashore animals of Japan with color pictures and keys. Hoikusha, Osaka, p xi-xxxv

Pilsbry HA (1916) The sessile barnacles (Cirripedia) contained in the collections of the U.S. National Museum; including a monograph of the American species. Bull US Natl Mus 93:1-366

Southward AJ, Burton RS, Coles SL, Dando PR and 5 others (1998) Invasion of Hawaiian shores by an Atlantic barnacle. Mar Ecol Prog Ser 165:119-126

Stubbings HG (1950) Earlier records of Elminius modestus Darwin in British waters. Nature 166:277-278

Utinomi H (1955) Studies on the cirripedia of Japan. II. Geographical distribution. Bull Biogeogr Soc Jpn 16-19: 113-123 (in Japanese)

Utinomi H (1966) Recent immigration of two foreign barnacles into Japanese waters. Proc Jpn Soc Syst Zool 2:36-39 (in Japanese)

Vallarino EA, Elias R (1997) The dynamics of an introduced Balanus glandula population in the southwestern Atlantic rocky shores: the consequence on the intertidal community. PSZN I: Mar Ecol 18:319-335

Yamaguchi T (1977) Taxonomic studies on some fossil and recent Japanese Balanoidea. Part I. Trans Proc Paleontol Soc Jpn, New Ser 107:135-160

Yamaguchi T (1987) Changes in barnacle fauna since the Miocene and the infraspecific structure of Tetraclita in Japan (Cirripedia; Balanomorpha). Bull Mar Sci 41:337-350

Yamaguchi T (1989) Foreign barnacles immigrated to Japan, with special reference to the changes in geographic distribution and ecology. Kanagawa Nat Hist Rep 10:17-32 (in Japanese with English abstract)

Young P (1995) New interpretations of South American patterns of barnacle distribution. Crustac Issues 10:229-253

Zevina GB (1980) Usonogie raki (Cirripedia; Thoracica) Beringova morya [Cirripedia in the Bering Sea]. In: Kudryashov VA (ed) Ekologia Obrastaniya v severo-zapadnoi chasti Tikhogo Okeana [Ecology of fouling in the NW part of the Pacific Ocean]. FESC AS USSR Press, Vladivostok, p 102-108

Zvyagintsev AY (2000) Fouling of ocean-going shipping and its role in the spread of exotic species in the sea of the Far East. Sessile Org 17:31-43

Submitted: June 10, 2002; Accepted: November 12, 2002 Proofs received from author(s): February 13, 2003 